Rice University's Baker Institute

LATIN AMERICA INITIATIVE

RICE UNIVERSITY'S 20 YEARS

BAKER INSTITUTE $2 O_{1993-2013}$

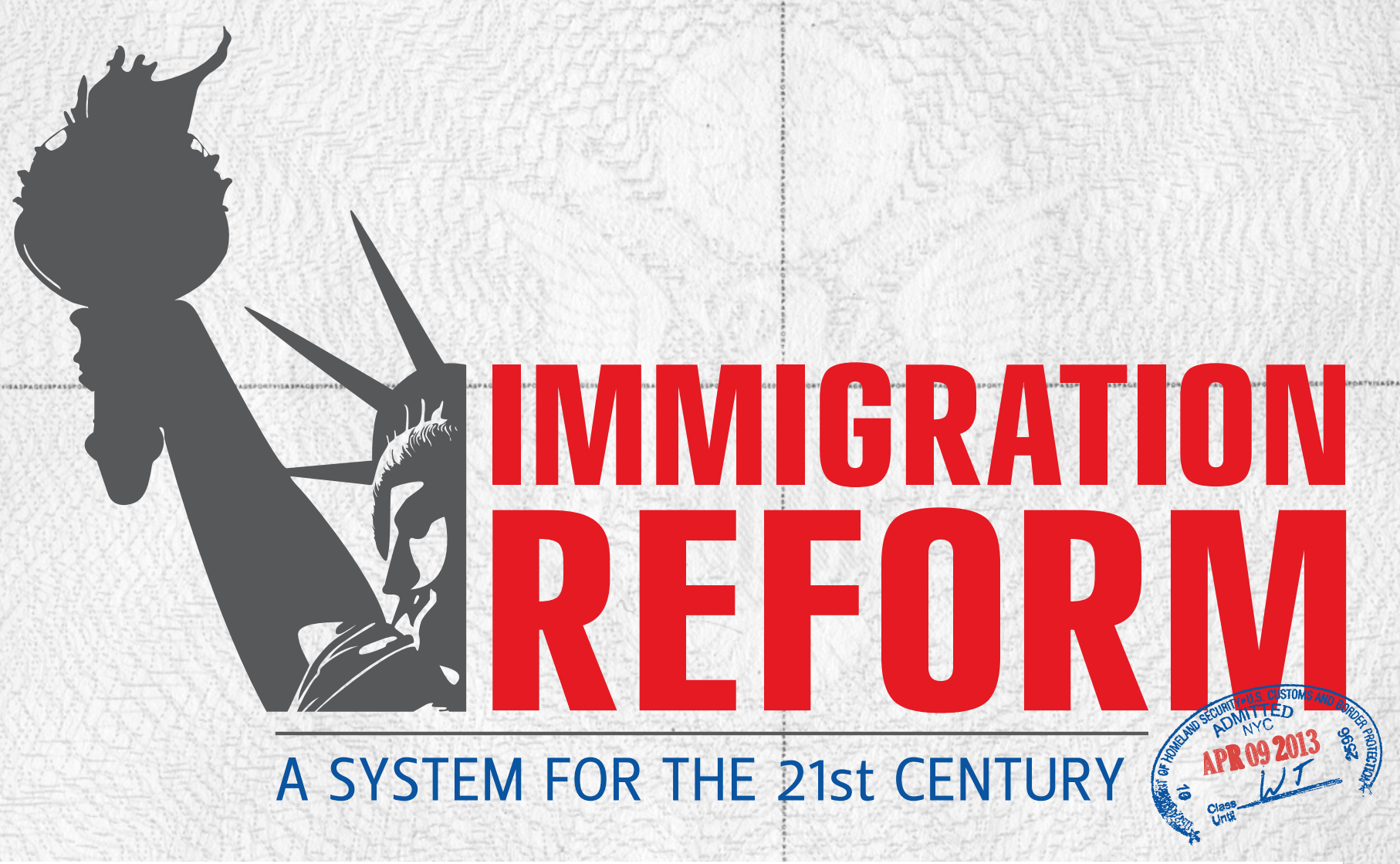

The Congressional Dynamics of Immigration Reform

Daniel J. Tichenor, Ph.D. 


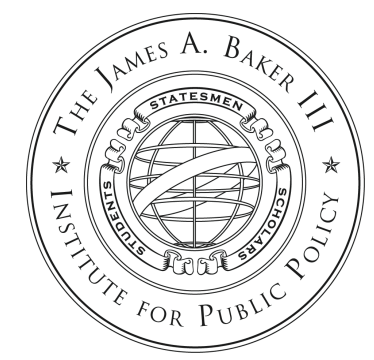

James A. Baker III Institute for Public Policy

RICE UNIVERSITY

Latin America Initiative ImMigration Research ProjeCt WORKING PAPER

\title{
THE CONGRESSIONAL DYNAMICS OF IMMIGRATION REFORM
}

\author{
BY \\ Daniel J. Tichenor, Ph.D. \\ Phillip H. KNight Professor of SOCial SCIENCE AND \\ Senior Faculty Fellow, WAyne Morse Center for LaW and Politics \\ UNIVERSITY OF OREGON
}

APRIL 2013 


\section{The Congressional Dynamics of Immigration Reform}

THESE PAPERS WERE WRITTEN BY A RESEARCHER (OR RESEARCHERS) WHO PARTICIPATED IN A BAKER INSTITUTE RESEARCH PROJECT. WHEREVER FEASIBLE, THESE PAPERS ARE REVIEWED BY OUTSIDE EXPERTS BEFORE THEY ARE RELEASED. HOWEVER, THE RESEARCH AND VIEWS EXPRESSED IN THESE PAPERS ARE THOSE OF THE INDIVIDUAL RESEARCHER(S), AND DO NOT NECESSARILY REPRESENT THE VIEWS OF THE JAMES A. BAKER III INSTITUTE FOR PUBLIC POLICY.

(C) 2013 By the James A. BAker III Institute for P UbliC POlicy Of RiCe University

THIS MATERIAL MAY BE QUOTED OR REPRODUCED WITHOUT PRIOR PERMISSION, PROVIDED APPROPRIATE CREDIT IS GIVEN TO THE AUTHOR AND THE JAMES A. BAKER III INSTITUTE FOR PUBLIC POLICY. 


\title{
The Congressional Dynamics of Immigration Reform
}

\begin{abstract}
Unauthorized immigration and the status of millions of undocumented immigrants in the United States are subjects that for years have spurred ferocious debate over the airwaves, on campaign trails and in statehouses across the country. Yet these fiery battles stood in bold contrast to the deep freeze that enveloped comprehensive immigration reform in the halls of Congress since the start of the Obama administration. But at the start of Obama's second term, the changing demography of American democracy produced the seemingly impossible: the emergence of significant, bipartisan legislation tackling this issue. This paper focuses on the congressional dynamics of American immigration reform. How Congress shapes immigration politics and policy reflects several recurrent and emergent patterns. One of the most important dynamics is the fact that the federal courts long have granted Congress sweeping control over immigration while the issue also generates distinctive partisan and intraparty conflicts that regularly bedevil major reform efforts. These political fissures point to a second pattern: Congressional action on immigration reform typically requires the formation of "strange bedfellow" alliances that are unstable and demand "grand bargains" to address disparate goals. The result is often legislation that introduces a new set of daunting immigration policy dilemmas. Finally, one of the most crucial dynamics of congressional immigration policymaking has been a shift over time from relatively insulated client politics to increased engagement by mass publics and key voting blocs. This expanding scope of conflict and its impact on congressional immigration politics receives the most extensive attention in this essay. In the contemporary politics of immigration reform, lawmakers now balance the demands of well-organized lobbies and advocacy groups with grassroots constituency pressures and electoral calculations.
\end{abstract}

\section{Introduction}

Unauthorized immigration and the status of millions of undocumented immigrants in the United States are subjects that for years have spurred ferocious debate over the airwaves, on campaign trails, and in statehouses across the country. Yet these fiery battles stood in bold contrast to the deep freeze that enveloped comprehensive immigration reform in the halls of Congress. As congressional scholars like Thomas Mann and Norman Ornstein have observed, the emergence 


\section{The Congressional Dynamics of Immigration Reform}

of increasingly "parliamentary parties" on Capitol Hill—parties that are ideologically polarized, internally unified, and vehemently oppositional - has yielded stalemate and dysfunction in a separation-of-powers system. And few issues rivaled illegal immigration for how great the divide was between the Democratic and Republican bases-an ideological distance replicated in Congress. ${ }^{1}$ Soon after entering office in 2009, the administration of President Barack Obama found it impossible to find key Republican lawmakers willing to work across the aisle on immigration reform. Obama officials responded to these hurdles by explaining that immigration legislation would have to come after more looming priorities such as economic stimulus, health care, and financial regulatory reform. ${ }^{2}$ Meanwhile, partly as a "down payment" on comprehensive reform, the Obama administration continued and expanded several enforcement programs initiated during the final years of the administration of President George W. Bush, deporting a record number of unauthorized immigrants in each of Obama's first two years in office.

What a difference an election makes. During the waning stages of the 2012 contest, Republican presidential nominee Mitt Romney appeared on an online forum broadcast by the Spanishlanguage Univision network to assure the mostly Latino audience that, if elected, he would achieve sweeping immigration reform, while also promising not to pursue mass deportation of the 10 million to 12 million undocumented immigrants living in the United States. The Romney campaign had invested heavily in ads on Spanish-language media in swing states from Colorado to Virginia, and had deployed his son Craig, who speaks Spanish, to help court Latino voters. These efforts represented a last-ditch attempt to minimize Obama's strong advantage among Latino voters, the fastest-growing ethnic group in the United States and a crucial voting bloc in pivotal swing states. Romney's difficulties with Latino (and Asian) voters stemmed from his endorsement during the GOP primaries of punitive state immigration laws that would encourage "self-deportation," but they reflected a deeper estrangement between the Republican Party and the nation's growing Latino population. In the end, Obama won 71 percent of the Latino vote with a 44-point advantage that was even more decisive than his 36-point margin (67 percent of the Latino vote) in 2008. When he began his first term, Obama later told Univision reporters, "we could not get ... a single Republican [senator], including the 20 who had previously voted for comprehensive immigration reform, to step up and say, 'we will work with you to make this 


\section{The Congressional Dynamics of Immigration Reform}

happen." At the start of his second term, the changing demography of American democracy produced the seemingly impossible: the emergence of significant, bipartisan legislation tackling one of the thorniest problems on the public agenda. The purpose of this paper is to illuminate the congressional dynamics of American immigration reform.

How Congress shapes immigration politics and policy reflects several recurrent and emergent patterns. One of the most important dynamics is the fact that the federal courts long have granted Congress sweeping control over immigration at the same time as the issue generates distinctive partisan and intraparty conflicts that regularly bedevil major reform efforts. These distinctive political fissures point to a second crucial dynamic: congressional action on immigration reform typically requires the formation of "strange bedfellow" alliances that are unstable and demand "grand bargains" addressing disparate goals. The result is often legislation that introduces a new set of daunting immigration policy dilemmas. Finally, one of the most crucial dynamics of congressional immigration policymaking has been a shift over time from relatively insulated client politics to increased engagement by mass publics and key voting blocs. This expanding scope of conflict and its impact on congressional immigration politics receives the most extensive attention in this paper. In the contemporary politics of immigration reform, lawmakers now balance the demands of well-organized lobbies and advocacy groups with grassroots constituency pressures and electoral calculations. Let us consider each of these dynamics in turn.

\section{Congressional Power and Disorienting Conflict: The Challenges of Immigration Reform}

Despite broad constitutional authority to regulate immigration, Congress largely avoided doing so until after the Civil War. By the 1880s, when federal lawmakers enacted draconian Chinese exclusion laws, the Supreme Court ruled that Congress could determine who may or may not be admitted to U.S. territory on whatever basis as it saw fit. In the Chinese Exclusion Case (1889), ${ }^{3}$ the Court underscored that Congress exercised "plenary" or absolute power to control immigration as part of its authority to assert U.S. national sovereignty and to shape foreign policy in the same way as it exercised the power to declare war or ratify international treaties. Only a few years later, the Court reinforced this "plenary power doctrine" in another Chinese exclusion decision: "Aliens enter and remain in the United States only with the license, 


\section{The Congressional Dynamics of Immigration Reform}

permission, and sufferance of Congress." ${ }^{\prime 4}$ The Court recently reaffirmed this doctrine in one of its blockbuster decisions of the summer of 2012, Arizona v. United States. This decision found that key provisions of Arizona's controversial SB 1070 - the so-called "show me your papers" law-were unconstitutional because they intruded on congressional primacy over immigration control. In sum, Congress' absolute power over alien admission and exclusion remains a central tenet of contemporary immigration law.

Arizona's restrictive law and others like it were symptoms of deep frustration at the state and local levels with more than a decade of gridlock on Capitol Hill over immigration reform. For Congress, logjams have emerged so regularly because the rival ideas and interests inspired by this issue make basic problem definition and legislative majorities elusive. The challenge has been more than partisan polarization. To be sure, the differences between Republicans and Democrats on immigration reform have been profound for years, but as recently as 2004 both major party platforms embraced comprehensive reform and a means for undocumented immigrants "to come out of the shadows" and enjoy "full participation in America." Immigration is a potent, crosscutting issue in American national politics, which defies the standard liberalconservative divide and often polarizes major party coalitions. This is hardly new; Americans have been arguing about and taking stands on immigration since the earliest days of the republic. There are four rather durable ideological traditions that have found expression in national debates and political struggles over immigration. Consider two dimensions. The first focuses on immigration numbers and divides those who support expansive immigration opportunities and robust numbers from those who favor substantial restrictions on alien admissions. The second concentrates on the rights of noncitizens residing in the United States and distinguishes those who endorse the provision of a broad set of civil, political, and social rights (as defined by T. H. Marshall) to newcomers from those who advocate strict limitations on the rights accorded to noncitizens. ${ }^{5}$ These two dimensions of immigration policy reveal tensions between cosmopolitans and economic protectionists on the left, and between pro-business expansionists and cultural protectionists and border hawks on the right. Tellingly, these conflicts are especially pronounced when the agenda focuses on unauthorized immigration and those residing in the country illegally. 


\section{The Congressional Dynamics of Immigration Reform}

The rival commitments of ideology and interest unleashed by illegal immigration make basic problem definition a tall order for policymakers. Indeed, recent immigration reform efforts have captured profoundly different assumptions and conceptions of what the problem is, or, for some, whether a problem even exists. Moreover, powerful organized interests and competing constituencies - from agribusinesses, service industries, and Microsoft to labor unions, ethnic and civil rights advocates, and church groups, to anti-immigrant activists of the Minuteman Project and Tea Party movement - regularly mobilize and clash over immigration reform. The resulting battles not only pit interest groups and constituencies allied with the Republican Party against those allied with the Democratic Party, they also divide organized interests within these partisan coalitions and sometimes even among those associated with the same interest or constituency, such as internal fights on this issue within the labor movement or among environmental and population control groups.

For cosmopolitans, or pro-immigration liberals, the problem is not the presence of millions of undocumented aliens in the United States, but rather their status as vulnerable, second-class persons. The chief imperative for these activists is to make the estimated 12 million unauthorized migrants living in the country eligible for legal membership. "What we want ... is a pathway to their legalization," Representative Luis Guiterrez (D-IL) explains, "so that they can come out of the shadows of darkness, of discrimination, of bigotry, of exploitation, and join us fully."6 Latino immigrants such as the journalist and scholar Edward Schumacher-Matos add that Hispanics have proven their loyalty to the nation in countless ways, including joining the military at higher rates than most groups, which "means that we have earned our say over the direction of the country ... and what we do on immigration."7 Legalization, or "earned citizenship," initiatives draw strong support today from immigrant advocate and civil rights groups; Latino, Asian, and other organizations; religious associations; and the leading federations of organized labor.

Economic protectionists have been particularly hostile toward illegal immigration, which they view as enhancing the wealth of corporate and professional America with little concern about the consequences for blue-collar workers or the unemployed. As much as Cesar Chavez complained bitterly in the late 1960s that undocumented Mexicans were being recruited to undermine his efforts to organize legal farmworkers, Carol Swain recently pointed to the deleterious "impact 


\section{The Congressional Dynamics of Immigration Reform}

that high levels of illegal immigration [are] having in the communities when it comes to jobs, when it comes to education, when it comes to health care." ${ }^{8}$ Former CNN newsman Lou Dobbs regularly sounds similar themes, claiming that illegal immigration has "a calamitous effect on working citizens and their families" and "that the industries in which illegal aliens are employed in the greatest percentages also are suffering the largest wage declines." "Economic protectionists endorse sanctions against unscrupulous employers who knowingly hire undocumented aliens, and they vehemently oppose guest worker programs, which they associate with a captive workforce subject to exploitation, abuse, and permanent marginalization. These views resonate among many rank-and-file members of labor unions and the constituencies of moderate Democrats in Congress.

For pro-immigration conservatives devoted to free markets and business growth, the chief problem is that existing federal policies fail to address "the reality," as former President George W. Bush put it, "that there are many people on the other side of our border who will do anything to come to America to work." In short, the U.S. economy has grown dependent on this supply of cheap, unskilled labor. ${ }^{10}$ For this camp, the solution lies in regularizing employers' access to this vital foreign labor; if the back door is to be closed, then this labor supply must be secured through temporary worker programs and an expansion of employment-based legal immigration. Powerful business groups in this camp also oppose employer sanctions and eligibility verification requirements as an unwelcome and unfair regulatory burden placed on American businesses large and small.

Finally, border hawks today see the illegal immigration problem as nothing short of an unprecedented breakdown of American sovereignty that compromises national security, the rule of law, job opportunities for citizens, public education, and social services. ${ }^{11}$ Mobilized by conservative talk radio, columnists, and television commentators, many Main Street Republicans are outraged that the nation's fundamental interest in border control and law enforcement has been trumped by the power of immigrant labor, rights, and votes. Amnesty or legalization proposals inspire hostile resistance from this camp, which views them as unethical rewards to those who break the rules and as stimulants to new waves of undocumented immigrants anticipating similar treatment. Likewise, temporary worker programs are scorned by these 


\section{The Congressional Dynamics of Immigration Reform}

activists, because many guest workers historically have remained in the country illegally, and because they contest the notion that only foreign workers will do certain menial jobs. Border hawks believe enforcement must come first. They favor a strengthened Border Patrol and tougher security measures along the nation's borders, as well as crackdowns on unauthorized immigrants and their employers within U.S. territory. They endorse a strategy of attrition in which targeted deportation efforts, workplace enforcement, and denial of social services and other public benefits would persuade many unauthorized migrants to return home.

It is difficult to imagine more widely divergent definitions of a public policy problem, or, concomitantly, more disparate blueprints for reform. Building majority support for legislation involving tough choices is always challenging, but it is especially so amid ideological disorientation and intraparty warfare. Clashing interests and ideals have meant that when policy initiatives are designed to meet the demands of one important constituency, they invariably incur the wrath of others, and the result has often been legislative paralysis, leaving in place a status quo in which unauthorized immigrants are a significant share of new inflows. As we shall see, these distinctive (cross-cutting) political fissures also have meant that congressional action on immigration reform typically requires the formation of "strange bedfellow" alliances that are unstable and demand "grand bargains" addressing disparate goals.

\section{Uneasy Coalitions and Faustian Bargains}

The long-standing linkage between the achievement of immigration reform and so-called "grand bargains" among unlikely political allies should hardly surprise us. The distinctive ideological traditions inspired by American political struggles over immigrant admissions and rights reminds us that none of the four major camps identified above has been able to secure significant policy innovation independently. Over time, major immigration reform almost invariably has required the building of incongruous Left-Right coalitions. Strange bedfellows not only abound in U.S. immigration politics, but uneasy alliances also make non-incremental policy change possible. Faustian bargains have been recurring features of national immigration policymaking. Let us consider four of these earlier congressional compromises and their implications for unauthorized flows. 


\section{The Congressional Dynamics of Immigration Reform}

\section{Mexican Labor and the First World War}

Ironically, the origins of America's illegal immigration dilemma can be traced to one of the most restrictive periods in our nation's history, namely, the early 20th century. This was a time when the federal government enacted a literacy test requirement for immigrants, a so-called Asiatic Barred Zone, a draconian national origins quota system, and an overall ceiling on annual overseas immigration that slowed European arrivals to a trickle. It was also a time when Mexican laborers were being recruited in steady numbers to develop a budding Southwestern economy. But new impediments to this labor stream emerged with enactment of the Immigration Act of 1917. The new law made all alien admissions contingent upon payment of an $\$ 8.00$ head tax and passage of a literacy test. The new requirements slowed the flow of Mexican workers across the southern border, although many simply crossed without inspection or official authorization. When the First World War began, the supply of Mexican laborers was more dramatically dampened when rumors that they would be drafted into the U.S. armed forces spurred a mass exodus. $^{12}$

Against this backdrop, southwestern growers, ranchers, miners, railroad companies, and supportive lawmakers pressured the Labor Department - then responsible for the Immigration Bureau and domestic enforcement - to facilitate the importation of thousands of Mexican workers. Bowing to this intense lobbying on the grounds that the war had produced labor shortages, Labor Secretary William Wilson invoked a special clause of the 1917 law (the ninth proviso of section 3 ) that enabled him to "issue rules and prescribe conditions ... to control and regulate the admission and return of otherwise inadmissible aliens applying for temporary admission." ${ }^{\prime 13}$ Wilson ordered that the literacy test, head tax, and contract labor restrictions be waived for Mexicans; he also led publicity efforts to assure potential guest workers that they would not be conscripted into the armed forces. Although Mexican contract labor was justified as an emergency wartime measure, an array of southwestern employers of low-wage labor joined with their congressional representatives in demanding extensions of the program after wartime hostilities ceased in 1918. The Labor Department again acceded to this lobbying pressure, as it did in subsequent years. Between 1917 and 1921, roughly 75,000 Mexicans worked as contract 


\section{The Congressional Dynamics of Immigration Reform}

laborers in the United States under Wilson's waiver plan, along with an indeterminate number of undocumented workers. $^{14}$

\section{"Restrictions ... with a bribe": Closing the Ports and Opening the Borders}

The issue of Mexican migratory labor threatened the immigration restriction movement in the 1920s. The diverse nativist coalition that emerged from the Progressive Era was united in its hostility toward Asian and southern and eastern European immigration, as well as in its devotion to eugenicist principles of racial order and Anglo-Saxon superiority. But Mexican labor flows were another matter. The northern Immigration Restriction League, the American Federation of Labor (AFL), patriotic societies, and a number of northern lawmakers favored stringent limits on Latin and South American immigration. By contrast, southern and western lawmakers and groups favoring national origins quotas for overseas immigration also extolled the virtues of a cheap and flexible Mexican labor force. Representative John Nance Garner (D-TX), President Franklin D. Roosevelt's future vice president, explained that "the prices that [Mexicans] charge are much less than the same labor would be from either the negro or the white man." 15 He assured his House colleagues that Mexican laborers were by definition temporary, powerless, and easily expelled. The Grange and the American Farm Bureau Federation adamantly opposed a change in Mexico's nonquota status. "We do not want to see the condition arise again when white men who are reared and educated in our schools have got to bend their backs and skin their fingers," business interests like the Great Western Sugar Company explained to Congress. "You have got to give us a class of labor that will do ... back-breaking work, and we have the brains and ability to supervise and handle the business part of it." ${ }^{\prime 16}$

The uneasy 1920s coalition of northern nativists, organized labor, and southern and western restrictionists were deeply divided over Mexican labor. The controversy seemed to place the national origins quota system begun in 1921 in jeopardy. Immigration defenders attempted to exploit these fractures within the nativist coalition during legislative debates of 1924, the year when the 1921 quotas were due to expire. Representatives Fiorello La Guardia (D-NY) and Adolph Sabath (D-IL) offered an amendment that placed strict quotas on Western Hemisphere countries. Their hope was to kill the 1924 quota legislation by sundering the disparate 


\section{The Congressional Dynamics of Immigration Reform}

restrictionist camp. Faced with stalemate or defeat, restrictionists called for a compromise on the divisive Mexican labor question. As one closed-border advocate declared, "I want the Mexicans kept out, but I do not want this bill killed by men who want these and all others admitted in unrestricted numbers." 17

The Immigration Act of 1924 ultimately erected formidable barriers to southern and eastern Europeans and reinforced Asian exclusion, but was decidedly permissive on Canadian and Mexican admissions. Aliens with 10 years continuous residence in a Western Hemisphere country could enter the U.S. as nonquota immigrants. "Restrictions of immigration and setting up of un-American racial tests has been enacted through a fusion of northern Republicans from urban districts with southern Democrats, with a bribe tossed to the latter by keeping Mexico open," observed one pro-immigration lobbyist. ${ }^{18}$ As nativist reformers prepared new quota legislation in 1928, they agreed to treat Mexican inflows as a distinctive issue. "These two kinds of restriction are quite separate and independent," New York restrictionist Demarest Lloyd declared in reference to overseas versus Western Hemisphere migration. "We all agree that unity of restrictionists is desirable."19 Recalling the potential split in 1924, the IRL also urged coalitional comity on "the National Origins-Mexican Quota situation."20 It even expressed sympathy for the dilemma faced by southwestern nativists. "Although the West has become racially conscious and wants to be a white civilization, it also wants to develop and to develop rapidly. For this it needs unskilled labor of a mobile type, like the Mexicans, for it cannot get white labor to do its unskilled work." ${ }^{21}$ The 1928 law codified this compromise, reaffirming a bifurcated system that imposed draconian restrictions on European and Asian immigration while remaining open and flexible toward labor inflows from Mexico and other Western Hemisphere countries.

\section{Mexican Braceros and Undocumented Aliens}

During the first New Deal, AFL leaders campaigned for legislation that would place national origins quotas on Mexico and other Western Hemisphere countries. In 1924, the AFL's Washington office vigorously pursued legislation that would establish a 1,500 annual quota for Mexican immigrants. But the AFL failed to build a broad coalition of support, and it faced 


\section{The Congressional Dynamics of Immigration Reform}

insurmountable opposition from the House and Senate Immigration Committees that were dominated by southern and western legislators who favored European and Asian restrictions but welcomed Mexican labor migration. ${ }^{22}$ By 1938, the Immigration and Naturalization Service (INS) reported that illegal immigration from Mexico was soaring due to the construction of new highways and "automobile travel."23 At the start of the Second World War, southwestern growers and other business interests, joined by their legislative champions, complained to executive branch officials that war-induced labor shortages necessitated a new Mexican temporary worker program. In response, an interagency committee was formed to facilitate the importation of Mexican guest workers. In 1942, the State Department negotiated a special agreement with Mexico establishing the Bracero Program that Congress swiftly approved. Under the bilateral agreement, the U.S. pledged that wages, living conditions, workplace safety, and medical services would be comparable to those of native workers. In turn, the Mexican government was to supervise the recruitment and contracting of braceros. ${ }^{24}$ Once the Bracero Program began, neither employers nor federal administrators saw that the negotiated protections of Mexican laborers were honored. Mexican braceros routinely received much lower wages than native workers and endured substandard living and working conditions. Contrary to the bilateral agreement, the INS permitted growers and other employers to directly recruit braceros at the border. If they resisted direct employer recruitment, one INS official recalled, "a good many members of Congress would be on the service's neck." 25 Tellingly, the Bracero Program endured for almost two decades after the war ended. Guarded by a "cozy triangle" of agribusinesses, southern and western congressional "committee barons," and a lax immigration bureaucracy, roughly 4.2 million Mexican workers were imported under the Bracero Program. Unauthorized flows across the southern border also continued apace.

During the early 1950s, influential restrictionist legislators such as Senators Pat McCarren (RNV) and James Eastland (D-MS) and Representative Francis Walter (D-PA) fervently guarded stringent limits on Asian, African, and southern and eastern European immigration. The McCarren-Walter bill promised to maintain the national origins quota system. As in the past, the AFL pledged support for the national origins quotas, but it joined other labor organizations in expressing alarm that Mexican braceros and unauthorized migrants had "depressed wages and destroyed working conditions." In 1951, the AFL proclaimed that the presence of hundreds of 


\section{The Congressional Dynamics of Immigration Reform}

thousands of braceros, coupled with an estimated 1.5 million undocumented aliens, compromised the "security" of American workers. Their appeal had no impact on the policy process. McCarren and Eastland shepherded passage of Public Law 78 reauthorizing the Bracero Program in 1951, claiming that termination would be "unfair to the farmer and the Mexican involved.",26

During floor action on the McCarren-Walter bill one year later, liberal Senator Paul Douglas (DIL) proposed legal sanctions against those who illegally smuggled aliens into the country and on employers who intentionally hired illegal aliens. But McCarran and Eastland successfully defeated the amendment; the final legislation contained language that made it unlawful to transport or harbor illegal aliens, but stipulated that "harboring" did not include employment of

unauthorized migrants. ${ }^{27}$ This "Texas proviso," as it later became known, highlighted the lengths to which many key congressional defenders of national origin quotas were willing to go to preserve Mexican labor flows, both legal and illegal.

After the 1960 election, the American Federation of Labor-Congress of Industrial Organizations (AFL-CIO) lobbied hard for the Bracero Program's termination. The administration of President John F. Kennedy and Democratic leadership in Congress lent their support to the effort. Yet growers and other business interests exerted considerable pressure of their own on members of Congress. The American Farm Bureau Federation, the National Cotton Council, the United Fresh Fruit and Vegetable Association, the National Beet Growers, ranchers, and other business interests rallied to save the Bracero Program. In 1961, these pressure groups won a two-year extension of the program but failed to win reauthorization in 1963 despite vigorous lobbying. Sweeping immigration reform in 1965 dismantled national origin quotas in favor of a new preference system that emphasized family-based immigration, but it also placed a 120,000 annual ceiling on Western Hemisphere visas. ${ }^{28}$ Reformers did not anticipate that this new ceiling and the end of the Bracero Program would swell unauthorized Mexican inflows.

\section{From Prolonged Gridlock to the Immigration Reform and Control Act of 1986}

The issue of illegal immigration inspired more media attention, public concern, and remedial proposals by policymakers than did any other migratory issue of the 1970s. In 1971, 


\section{The Congressional Dynamics of Immigration Reform}

Representative Peter Rodino (D-NJ), chair of the House Judiciary Committee's Subcommittee on Immigration, led pro-labor liberals in the pursuit of employer sanctions legislation to resolve the perceived illegal immigration crisis. ${ }^{29}$ Rodino's employer sanctions legislation initially passed the House in 1972 but languished in the Senate where Eastland refused to allow the Judiciary Committee he chaired to take action. ${ }^{30}$ When Rodino reintroduced his bill a year later, new resistance emerged in the House from fellow Democrats who warned that the measure would lead to job discrimination against Latinos, Asians, and anyone who looked or sounded foreign. ${ }^{31}$ By 1977, the administration of President Jimmy Carter ignored the warnings of congressional Democratic leaders when it proposed a comprehensive plan for addressing illegal immigration. The reform package included stiff civil and criminal penalties who engaged in a "pattern or practice" of hiring undocumented aliens; use of the Social Security card as an identification document for verifying employee eligibility; enhanced Border Patrol forces at the Mexican border; and an amnesty program that would confer legal resident alien status on all aliens living in the country before $1970 .{ }^{32}$ The White House proposal galvanized opposition from all sides in Congress. Lawmakers with ties to growers and other business interests argued that sanctions were unfair to employers; those aligned with the National Council of La Raza and the MexicanAmerican Legal Defense and Education Fund (MALDEF) saw the measure as detrimental to civil rights; and law and order conservatives complained that the plan rewarded lawbreakers with amnesty. ${ }^{33}$ With immigration reform mired in conflict, Congress formed a bipartisan Select Commission on Immigration and Refugee Policy (SCIRP) to study the "illegal immigration problem" and all other facets of U.S. immigration and refugee policy and issuing recommendations for future reform.

The SCIRP completed a sweeping final report in 1981 that portrayed "lawful immigration" as "a positive force in American life," serving the national interest in terms of economic growth and productivity, reuniting families, and advancing key foreign policy imperatives. ${ }^{34}$ But it also concluded that illegal immigration was an urgent problem that needed to be controlled before legal immigration could be expanded. The SCIRP noted that unauthorized entries created a vulnerable shadow population that had few incentives to report crimes, health problems, or exploitation by employers. ${ }^{35}$ It also asserted that unrestrained illegal immigration encouraged a perilous disregard for the rule of law: "illegality erodes confidence in the law generally, and 


\section{The Congressional Dynamics of Immigration Reform}

immigration law specifically. ${ }^{, 36}$ To address the problem, the SCIRP endorsed the familiar scheme of enhanced Border Patrol resources and employer sanctions. But it also underscored the notion that the efficacy of sanctions hinged upon faithful enforcement and the development of a tamper-resistant national identification card as the linchpin of a security and universal system of employee eligibility. All 16 commissioners also agreed on a generous legalization program for undocumented aliens already residing in the country. ${ }^{37}$

Two young lawmakers-Senator Alan Simpson (R-WY), who served on the SCIRP, and Representative Romano Mazzoli, a moderate Kentucky Democrat with ties to the SCIRP chair Father Theodore Hesburgh — took the lead in pressing for immigration reform. Early in 1982, the pair introduced omnibus legislation on illegal and legal immigration. The measure met fierce resistance from a broad coalition of business interests (the U.S. Chamber of Commerce, National Association of Manufacturers, agribusinesses, the Business Roundtable), ethnic and civil rights groups such as NCLR and MALDEF, the ACLU, religious lobbies, and a new immigrant rights organization, the National Immigration Forum. Left-Right opposition to the Simpson-Mazzoli initiative was reflected in the resistance of both the administration of President Ronald Reagan, which saw employer sanctions and national identification cards working at cross-purposes with its regulatory relief agenda, and House Democrats led by the Hispanic and black caucuses, which raised familiar concerns about discriminatory impacts of sanctions and other provisions. Gridlock was overcome only after three more years of wrangling, and the resulting Immigration Reform and Control Act of 1986 (IRCA) depended upon a compromise package, watered-down employer sanctions provisions, legalization for undocumented aliens living in the country since 1982, and a new Seasonal Agricultural Worker program to appease grower interests.

The measure proved highly successful in granting legal status to nearly three million undocumented aliens, but employer sanctions proved to be a "toothless tiger." This was largely by design: in the absence of a reliable identification system for verifying employee eligibility that the SCIRP described as a linchpin for effective enforcement, the employer sanctions provisions lacked teeth. By the late 1980s, it was clear to national policymakers that the IRCA had done virtually nothing to discourage illegal immigration. But legislators were eager to shift their attention to the politically painless task of expanding legal immigration. The Immigration 


\section{The Congressional Dynamics of Immigration Reform}

Act of 1990 unified cosmopolitans and free market expansionists behind a 40 percent increase in annual visa allocations that benefited both family-based and employment-based immigration. ${ }^{38}$ The "grand bargains" of the 1980s, like their forebears, left key dilemmas posed by unauthorized immigration for future Congresses to resolve.

\section{Expanding the Scope of Conflict: Huddled Elites and Popular Mobilization}

A little more than a decade ago, Gary Freeman used frameworks developed by James Q. Wilson and Theodore Lowi to argue that immigration policymaking produced "concentrated distributive policies and client politics." By this, he meant that political elites advanced immigration policies that rewarded organized groups with concentrated benefits over unorganized bearers of diffused costs. In this fashion, the Immigration Reform and Control Act of 1986 was the product of huddled Washington elites who distributed benefits to organized agribusinesses and immigrant advocates, limited sanctions on organized business groups, and did little to please unorganized mass publics. However, anti-immigrant populism, immigrant enfranchisement, and competitive democratic elections have altered this equation. That is, one of the most crucial dynamics of congressional immigration policymaking since the 1990s has been a transition from relatively insulated client politics to more popular engagement via stronger grassroots pressure and greater "electoral connections" for lawmakers. The scope of conflict in American politics over immigration reform is greater now than it has been for generations. ${ }^{39}$

Signs of popular restiveness on unauthorized immigration emerged early in the 1990s. Beyond the Washington Beltway, organizations dedicated to immigration restriction began to mobilize grassroots support in key receiving states such as California, Texas, and Florida. ${ }^{40}$ Activists in California formed a group called Save Our State (SOS) to promote Proposition 187, a measure designed to deny undocumented immigrants and their children welfare benefits, nonemergency health care, and public education. ${ }^{41}$ California governor Pete Wilson (R) threw his support behind SOS during his 1994 reelection campaign, calling for wholesale restrictions on immigrant access to public benefits. His staunch support and an endorsement from the state GOP tied Proposition 187 to the Republican brand. ${ }^{42}$ 


\section{The Congressional Dynamics of Immigration Reform}

Popular support for restricting immigration also seemed to intensify across the country by 1994. Immigration restriction not only gained in popularity in 1994 (roughly 65 percent favored major reductions in legal admissions), but its salience for the general public also appeared to surge. ${ }^{43}$ When ordinary citizens were asked which issues mattered most to them in the 1994 election, 20 percent placed illegal immigration at the top of their lists; the most common answers were crime at 33 percent and welfare reform at 28 percent. ${ }^{44}$ Another poll conducted just before the election found that 72 percent of respondents saw mass immigration as a "critical threat" to the "vital interests of the United States."45 Jack Citrin and his colleagues found that voters were increasingly connecting immigration to negative economic experiences and economic uncertainty in the two elections after 1992. ${ }^{46}$ Events like the 1994 bombing of the World Trade Center in New York City by Islamic terrorists, who had gained entry into the country with relative ease, heightened public anxieties over international migration.

When the dust settled on a contentious California race in November 1994, Wilson won reelection and Proposition 187 carried the state with 59 percent of the vote. However, the measure was stopped cold by a federal court that held that its denial of public education to the children of undocumented aliens was unconstitutional. If judicial intervention blunted popular assaults on immigrant rights at the state level, a dramatic changing of the guard in Congress seemed to offer new opportunities for restrictionist policy innovations supported by large majorities of the public. For the first time since 1952, Republicans gained control of both houses of Congress. GOP leaders in Congress, conscious of the success of Proposition 187 and opinion poll trends, weighed the potential of restrictive immigration reform a "wedge" issue to win crucial bluecollar Democratic votes (especially in key battleground states like California and Florida). ${ }^{47}$ House Speaker Newt Gingrich responded to intraparty pressures by creating a special task force on immigration reform chaired by Edward Gallegly (R-CA), known for his hard line on illegal immigration and legal immigrant welfare eligibility. Senate Majority Leader Robert Dole (R-KS) joined many fellow partisans in supporting immigration curbs, appearing on television to decry the unfair immigration costs imposed on California, Florida, and Texas, and to denounce policymakers "not willing to protect our borders." 48 


\section{The Congressional Dynamics of Immigration Reform}

At the same time, other congressional conservatives saw robust immigration as consistent with business demands for foreign labor, entrepreneurship, refugee relief for those fleeing communist regimes, and a pro-family agenda. ${ }^{49}$ Dick Armey (R-TX) was one of several prominent figures of the House Republican leadership team who vigorously defended expansive legal immigration. Republican lawmakers faced especially strong lobbying from various businesses that relied on skilled and unskilled immigrant labor. As Microsoft lobbyists chastised restrictionists for missing "the point that to succeed in foreign markets, you need foreign personnel," the National Association of Manufacturers warned that "this country is not producing the workers we need to be globally competitive." ${ }^{50}$ Employers of unskilled workers also made their presence felt on Capitol Hill. During a meeting with lobbyists for the National Restaurant Association, an organization whose large membership relied heavily on unskilled alien workers, House leaders

offered assurances that they had no intention of cutting their supply to immigrant labor. ${ }^{51}$ "Immigration yes, welfare no!" was the rallying cry of pro-immigration conservatives in Congress. As Gingrich proclaimed on the House floor, "Come to America for opportunity. Do not come to America to live off the law-abiding American taxpayer.",52

In keeping with their fealty to civil rights, most Democrats on Capitol Hill defended both legal immigration and the rights of noncitizens to receive public benefits. But fighting unauthorized immigration had become a valence issue that attracted strong bipartisan support. Not to be outflanked on illegal immigration, the Clinton White House repeatedly denounced unauthorized immigration and issued an executive order early in 1996 that denied federal contracts to businesses that knowingly hired undocumented immigrants. ${ }^{53}$ The decoupling of legal and illegal immigration, combined with popular restiveness on unauthorized flows, made all the difference for legislative action. The Illegal Immigration Reform and Immigrant Responsibility Act (IIRIRA) of 1996 passed with large bipartisan majorities: 333 to 87 in the House and 97 to 3 in the Senate. IIRIRA enhanced the federal border controls, tightened asylum procedures, limited immigrant access to public benefits, required U.S. financial sponsors for newcomers, and established stringent provisions for criminal and undocumented immigrants. Getting tough on unauthorized immigration, then, was a bipartisan cause in the 1990s. 


\section{The Congressional Dynamics of Immigration Reform}

Strikingly, if the IIRIRA was the extent of congressional action affecting immigrants, the differences between the major parties would have been negligible. Yet Republicans in Congress joined against Democrats to establish new bars on welfare benefits for immigrants, both legal and undocumented. The Personal Responsibility and Work Opportunity Act of 1996 (PRWOA) denied a broad set of federal benefits programs to noncitizens. President Clinton told the press that he and Democratic lawmakers were offended by the legislation's harshness toward legal immigrants. Republican congressional leaders expressed optimism behind closed doors that the immigration issue would help them shore up additional working-class votes. ${ }^{54}$ At the start of the 1996 election, Pete Wilson made immigration control a signature feature of his short-lived presidential campaign; Pat Buchanan assailed Third World immigration as a source of economic and cultural insecurity at home; and Bob Dole, the eventual GOP standard bearer, associated himself with the stringent immigration enforcement measures then working their way through Congress. ${ }^{55}$ The 1996 Republican platform pledged support for national legislation barring children of undocumented aliens from public schools. What these politicians did not anticipate was a formidable Latino and Asian backlash against what were perceived as anti-immigrant reforms.

The first sign of political mobilization among immigrants and kindred ethnic groups came in the form of soaring naturalization rates: more than one million immigrants became citizens in 1996 alone. The Clinton White House also instructed the Immigration and Naturalization Service (INS) to implement the so-called Citizenship USA initiative. In the words of the agency, the initiative "was designed to streamline the naturalization process and greatly increase naturalizations during 1996." Voter registrations among Latinos grew by 1.3 million, or 28.7 percent, between 1992 and 1996; the percentage of Latinos on the voter rolls rose from 59 percent of those eligible in 1992 to 65 percent in 1996. Late in the 1996 campaign, Dole and other Republican candidates took heed of new reports that immigrants and kindred ethnic groups had become energized by anti-immigration politics. But it was too late for backpedaling. The results of the 1996 election left little doubt about two crucial developments: immigrants comprised the nation's fastest growing voting bloc and Democrats were the immediate beneficiaries of their emergent electoral clout. The electoral dividends for Clinton were particularly strong: he won 72 percent of the Latino vote in 1996 (up from 60 percent in 1992). 


\section{The Congressional Dynamics of Immigration Reform}

Asian voters, a smaller yet important swing bloc, increased their support for the Democratic ticket in the same years from 29 to 43 percent. ${ }^{56}$ Dole registered an all-time GOP low of 21 percent of the Latino vote in 1996, and he became the first Republican presidential candidate to lose Florida since Gerald Ford in 1980.

Between 1990 and 2000 in sheer numbers, more immigrants arrived in the United States than during any previous period in American history. In this decade alone, the immigrant population in the United States grew by roughly one million persons per year, rising from 19.8 million to 31.1 million. Immigration reform was not among the 10 items that Gingrich and House Republicans promised to address in their "Contract with America." Yet Gingrich and many of his lieutenants calculated that making immigrants ineligible for welfare, new crackdowns on illegal immigration, and the Gallegly amendment would pay electoral dividends among agitated native-born voters in states from California to Florida, especially working-class Americans. Dole accepted the same bet in his presidential bid. In the end, it cost them dearly among naturalized voters and kindred Latino and Asian constituencies who associated the GOP with measuresfrom Proposition 187 to PRWOA - that they saw as draconian and anti-immigrant.

By the 2000 election, Republican national and state organizations drew up plans to attract new Asian and Latino voters. They were emboldened by party strategists who warned that "if we're only getting 25 percent of the Hispanic vote, you wait three, four presidential elections, and we'll be out of business." Then-Texas governor George W. Bush was hailed by many party leaders as the ideal candidate to court new immigrant voters in 2000, and he reminded Latinos throughout the campaign that early on he had "rejected the spirit of Prop 187," opposed "English-only" proposals, and refused "to bash immigrants" when it was popular. Vice President Al Gore in turn reminded Latino and Asian constituencies that Republicans led the way in stripping welfare benefits and other rights for noncitizens, and assured them that Democrats would continue to defend expansive legal immigration. Yet Bush dramatically outspent Democrats in his appeal to Latino voters in 2000, devoting millions of campaign dollars to Spanish-language advertising and direct mail appeals. He also gave television interviews in Spanish, and had his bilingual nephew George P. Bush stump for him extensively among Latino constituencies. ${ }^{57}$ Bush's "compassionate conservatism" on immigration policy and his direct campaigning had clear 


\section{The Congressional Dynamics of Immigration Reform}

electoral ramifications. An estimated 7.8 million Latino voters, or 6 percent of all voters (up from 4 percent in 1996), cast ballots in the 2000 election. Gore maintained the Democrats' traditional edge in Latino voting, but Bush gained an estimated 34 percent among Latinos-13 points higher than Dole's 1996 total and only 3 points off the previous GOP record of 37 percent attained by Ronald Reagan in the 1984 election. ${ }^{58}$ The Bush team clearly was focused on adding more Latinos, the fastest growing sector of the electorate and a crucial swing constituency in battleground states, to the GOP base.

Bush and Mexico's president, Vincente Fox, took office within a few months of each other, and they soon began bilateral talks about a new temporary worker program and ways to legalize several million undocumented Mexicans living in the U.S. Fox and Bush portrayed themselves as "common-sense ranchers" who wanted to make the flow of persons across their shared border "safe, orderly, and legal." During a September 6, 2001, visit to Washington, Fox called for a joint agreement on a guest worker program and legalization "by the end of the year" and Bush replied that he intended to "accommodate my friend" and hailed Mexico as the United States' most important ally. ${ }^{59}$ But discussions ended abruptly after the terrorist attacks five days later.

In the wake of the 9/11 attacks and its transformation of the immigration policy environment, the Bush administration felt it had little choice but to set aside comprehensive reform. Border hawks like Representative Thomas Tancredo (R-CO) made headlines in December 2001 by underscoring how porous borders presented an appalling national security problem. Organized interests favoring immigration restriction and strict border control ran ads around the country blaming lax immigration policies for the September 11 terrorist attacks. Plans for a guest worker program and legalization fell off the agenda. Relations with Mexico's Fox also cooled as Bush postponed any relaxation of immigration laws and Fox vigorously opposed the U.S.-led invasion of Iraq.

In the fall of 2003, the AFL-CIO supported hotel workers when they took the lead in organizing the Immigrant Workers Freedom Ride, a national mobilization intended to evoke the civil rights movement's 1961 Freedom Rides. Organized labor became a strong champion of legalizing undocumented workers in the late 1990s when it became clear that foreign-born union 


\section{The Congressional Dynamics of Immigration Reform}

membership was growing sharply while native-born membership was dropping. ${ }^{60}$ During the Democratic presidential primaries several months later, leading candidates endorsed "earned legalization" programs that would provide green cards for undocumented immigrants. As Democrats in debates described immigration reform as "another broken promise" by Bush, word leaked to reporters that "the White House feels it's got to get its irons in the fire now" or risk losing ground with Latino voters in November. ${ }^{61}$ Wasting little time as he kicked off his reelection year, Bush unveiled a major immigration reform plan in the first week of January 2004 that made a new guest worker program its centerpiece. "The president has long talked about the importance of having an immigration policy that matches willing workers with willing employers," White House Press Secretary Scott McClellan explained. "It's important for America to be a welcoming society.",62

Tellingly, the harshest criticism of Bush's reform blueprints came from conservative members of his own party in Congress. Tancredo made cracking down on unauthorized immigration his signature issue, and he chided Bush for rewarding people who break the law. Ed Gallegly (RCA) mocked the White House for becoming "the Mexican Department of Social Services." ${ }^{63}$ At a Republican retreat in Philadelphia later in the month, senior Bush adviser Karl Rove got an earful from outraged members of Congress who claimed that their constituents were overwhelmingly opposed to the Bush proposal and that "Hispandering" for votes would create a voter backlash within the party's base. ${ }^{64}$ Yet the president's closest advisers were convinced that his immigration proposal would help with Latino voters without sacrificing support from his conservative base. "It's more conservative pundits than conservatives," one adviser observed of conservative radio, television, and print commentators versus rank-and-file voters. Grover Norquist, president of the conservative Americans for Tax Reform and a key pro-business advocate of the president's guest worker program, agreed that immigration reform was a safe strategy to win Latino votes without threatening the Republican base. "It's not a vote-moving issue for any bloc of the center-right coalition," he asserted. "People vote on guns. They vote on taxes. They vote on being pro-life." 65 By March 2004, a truce was called on immigration battles within the Republican Party and Bush quietly put his immigration proposal aside for the rest of the campaign. ${ }^{66}$ 


\section{The Congressional Dynamics of Immigration Reform}

The 2004 election returns validated Rove's calculation that courting Latino voters with proimmigrant rhetoric and a relatively expansive reform proposal could be done without losing ground among voters in the Republican base. Bush's reelection bid produced unprecedented mobilization and support from his partisan base, and it also yielded a GOP record 40 percent of the Latino vote. ${ }^{67}$

Soon after the election, Bush met privately with pro-immigration House and Senate Republicans on a new guest worker program that would grant legal status to millions of undocumented immigrants. Immigration reform became the key post-election talking point of Secretary of State Colin Powell, Department of Homeland Security Secretary Tom Ridge, and chief strategist Karl Rove, the latter telling reporters that it was striking that Bush did not lose votes among his conservative base in the election. ${ }^{68}$ Press secretary McClellan added that immigration reform was "a high priority" that the president "intends to work with members on to get moving again in the second term." Border hawks were aghast. One lobbyist for the immigration restriction movement doubted that Republican lawmakers would follow the administration "over a cliff" on the issue. ${ }^{69}$ He was right. In late November, House Republicans blocked an intelligence overhaul bill to signal Bush that his immigration initiative would split the party and stall action in his second term. $^{70}$ Tancredo scorched the White House as abandoning conservative law-and-order values, proclaiming that "their amnesty plan was dead on arrival ... in January, and if they send the same pig with lipstick back to Congress next January, it will suffer the same fate." 71 Many Republicans leaving a House Republican Conference the same month echoed his views. One Republican leader anonymously observed that it was "highly unusual for the administration to use their political capital that was given by the base against the base."72

Polls indeed found that most conservative Republicans disapproved of plans for granting legal status to undocumented immigrants. In truth, however, the business base of the Republican Party was a strong and unwavering supporter of the president's guest worker plans throughout his two terms in office. The most active business lobbyists favoring the Bush initiatives formed the Essential Worker Immigration Coalition (EWIC), an alliance of immigrant-dependent industry associations headed by the U.S. Chamber of Commerce. The coalition would bring together powerful associations like the American Health Care Association, the American Hotel and 


\section{The Congressional Dynamics of Immigration Reform}

Lodging Association, National Council of Chain Restaurants, the National Retail Federation and the Associated Builders and Contractors. EWIC was initially formed by meatpacking conglomerates to advocate for expansion of guest worker programs, and counts many of the nation's largest employers as members, including Wal-Mart, Tyson Foods, and Marriott. ${ }^{73}$

Nevertheless, porous borders and unauthorized immigration were hot-button issues for many grassroots Republicans, and their disquietude was fueled by local and national talk radio, television commentators like Lou Dobbs and Pat Buchanan, and restrictive politicians such as Tancredo and his House Immigration Reform Caucus. New citizen patrols also popped up along the U.S.-Mexican border. In 2004, an accountant and decorated former Marine, James Gilchrist, founded the all-volunteer Minuteman Project to patrol the Arizona border armed with binoculars and cell phones. Former California schoolteacher Chris Simcox established the separate Minutemen Civil Defense Corps as an extension of this citizen patrol movement. ${ }^{74}$ Described as "vigilantes" by Bush, surveys showed that Republican voters strongly approved of the Minuteman movement. ${ }^{75}$

In the winter of 2005, HB 4437, a punitive bill focused on border enforcement, narrowly passed the Republican-controlled House. It proposed for the first time to make unauthorized presence in the United States a felony, and made it a crime to lend support to undocumented immigrants. From March through May 2006, demonstrations against the bill by largely Latino immigrants and their supporters, unprecedented in number and size, took place in a wide array of cities and towns across the United States. ${ }^{76}$ These nationwide rallies, protests, and boycotts drew negative reactions from most Americans: just 24 percent offered a favorable view of the immigrant rights protests and protestors, while 52 percent expressed disapproval. ${ }^{77}$ Overall, however, public opinion remained open to varied policy solutions: majorities favored legal status and earned citizenship for undocumented immigrants, stricter employer penalties, and tougher enforcement. ${ }^{78}$ Strikingly, 60 percent of Republicans backed Bush's plan, a number that would dwindle steadily in coming months. ${ }^{79}$ By the fall of 2006, Bush sought to appease enforcementminded conservatives by endorsing the Secure Fence Act of 2006, which authorized the construction of a 700-mile fence along the 2,100-mile U.S. border with Mexico. Signed just 12 days before the midterm elections, Bush used the occasion to urge moderation to assembled 


\section{The Congressional Dynamics of Immigration Reform}

House and Senate Republicans. "There is a rational middle ground between granting an automatic path to citizenship for every illegal immigrant and a program of mass deportation," he observed, "and I look forward to working with Congress to find that middle ground." 80

The midterm elections gave Democrats control of the House and Senate, but their ranks now included new moderate Democrats from culturally conservative swing districts that favored enforcement first. In the summer of 2007, a bipartisan Senate coalition led by Edward Kennedy (D-MA) and John McCain (R-AZ), old hands at immigration reform, negotiated with the White House on a new compromise bill. The result was the Border Security and Immigration Act of 2007, a "grand bargain" that had the support of President Bush and became the focus of all meaningful subsequent discussion. ${ }^{81}$ The bargain included a new $\mathrm{Z}$ visa for undocumented immigrants that covered "a principal or employed alien, the spouse or elderly parent of that alien and the minor children of that alien" currently living in the U.S., provided they pay fees and penalties that could total as much as $\$ 8,000$, and a "touchback provision" requiring the leader of the household to return home before applying for legal permanent residency status. It also contained a temporary Y worker program of about 200,000 that would allow workers to be admitted for a two-year period, which could be renewed twice, as long as the worker spent a period of one year outside of the U.S. between each admission (which eventually had a five-year sunset provision). Incorporating the White House proposal, the bill contained triggers to be met before the $\mathrm{Z}$ or $\mathrm{Y}$ visas could begin. These triggers included: 18,000 border patrol hired, construction of 200 miles of vehicle barriers and 370 miles of fencing, resources to detain up to 27,500 persons per day on an annual basis, and the use of secure and effective identification tools to prevent unauthorized work.

Subject to intense media scrutiny and commentary, the public response to the compromise Senate immigration plan ranged from hostile to tepid. Many members of Congress were deluged with angry phone calls, emails, and letters from constituents and other activists. Surveys indicated that a majority of Republicans, Democrats, and independents opposed the measure, with only 23 percent in favor. Significantly, most Americans opposed the initiative not because they opposed "amnesty" or other proposals for legalizing millions of undocumented immigrants

in the country (roughly two-thirds supported earned citizenship options over deportation), but 


\section{The Congressional Dynamics of Immigration Reform}

rather because they had little trust that it would provide genuine border security. More than 80 percent in surveys said they did not believe that the Kennedy-McCain bill would reduce illegal immigration or enhance border control. ${ }^{82}$

This profound cynicism born of past implementation failures was a powerful theme for many lawmakers of both parties who lined up against the "grand bargain." Senator Byron Dorgan (DND) recalled believing the promises of the Simpson-Mazzoli Act when he was in Congress in 1986, and later discovered that "none of them were true, and three million people got amnesty. There was no border security to speak of, no employer sanctions to speak of, and there was no enforcement." Robert Byrd (D-WV) vowed "not to make the same mistake twice," while Charles Grassley said, "I was fooled once, and history has taught me a valuable lesson." 83 Dorgan and Grassley would be among dozens of senators proposing amendments designed to derail the bill.

The Kennedy-McCain compromise had the makings of vintage client politics. As Freeman's theory predicts, organized interests likely to receive concentrated benefits from the reform formed a familiar strange bedfellow alliance. The bill was the result of careful negotiations that ultimately won the support of Essential Worker Immigration Coalition (EWIC) and other business lobbies; the National Council of La Raza (NCLR) and various ethnic and civil rights groups; the American Civil Liberties Union (ACLU); and labor unions like the Service Employees International Union (SEIU), Hotel Employees and Restaurant Employees Union (HERE), and the United Farm Workers. Yet the scope of conflict had exploded, and a repeat of the behind-the-scenes congressional deals that produced IRCA in 1986 were not in the offing two decades later. In late June, angry constituents, organized interests from the AFL-CIO to restrictionist lobbies, and both conservative and liberal lawmakers successfully blocked cloture on the Senate bill and thereby dashed hopes of avoiding killer amendments. ${ }^{84}$ Fox News polling reaffirmed that conservatives were bitterly opposed to the bill and disenchanted with Bush, while Democratic poll conducted by Stan Greenburg showed Democratic identifiers to be split 47 percent for and 47 percent against the bill. ${ }^{85}$

With the measure close to death, the White House and a small bipartisan group of Senators worked quietly on a last ditch effort to save the compromise plan. Their private negotiations 


\section{The Congressional Dynamics of Immigration Reform}

drew fire from all sides in the summer of 2007. "The process has been orchestrated by a handful of people behind closed doors," Senator Bob Corker (R-TN) observed, "and they are paying a price for that." ${ }^{\prime 86}$ In truth, closed-door negotiations represented the primary means that an unpalatable compromise could be brokered among disparate interests. Yet the forces arrayed against this last ditch effort were overwhelming, from the grassroots to the halls of Congress. Ultimately, the "grand bargain" developed by Bush, Kennedy, and McCain fell 14 votes short of the 60 needed to force a final vote. Fifteen Democrats were among those who helped kill the bill, including freshman senators from swing states such as Claire McCaskill (Missouri), Jon Tester (Montana), and Jim Webb (Virginia). ${ }^{87}$

Bush had pursued comprehensive immigration reform out of a strong personal conviction that the best solution to the bedeviling problems associated with unauthorized flows was an expansive guest worker program that matched willing employers and willing laborers. He also believed that stricter enforcement of employer sanctions, improved efforts at the border, and earned citizenship for undocumented immigrants were necessary features of an effective compromise package. Finally, he and his advisers also were convinced that public opinion could be swayed on the issue, that his conservative base would hold and not rebel, and that his compassionate pragmatism on immigration reform would draw large numbers of Latino voters into the Republican fold. Tellingly, whatever inroads were made in 2000 and 2004 with Latinos and other new immigrant voters were forgotten by 2008 when another immigrant-friendly Republican stood atop the ticket. Consistent with trends that began in 2005 when Latinos soured on Bush's immigration plan and on House Republicans viewed as anti-immigrant, Barack Obama and Democrats dominated the Latino vote in 2008 with more than two-thirds support in crucial battleground states from Florida to the Southwest. Equally troubling to Republicans was the fact that Latino turnout increased to 11 million voters (9 percent of the total) in 2008 , double the turnout in $2000 .^{88}$

Undaunted by Bush's quixotic struggles for comprehensive immigration reform only a few years before, Obama ran for president pledging to win a bipartisan compromise package would enhance border control while extending legal status to roughly 12 million undocumented immigrants. In the two previous presidential elections, both major party candidates touted strong 


\section{The Congressional Dynamics of Immigration Reform}

pro-immigration credentials as they courted immigrant and co-ethnic Latino and Asian voters. During the 2008 campaign, however, Obama's position on immigration distinguished him from his Republican opponent, John McCain, who assumed a tough enforcement stance. McCain, once committed to comprehensive reform and guest worker programs, became an eleventh-hour border hawk during the primaries to appease a partisan base adamantly opposed to extending legal status to unauthorized immigrants no matter how long they lived in the country. When the dust settled, Obama's pro-immigration appeals helped him garner 67 percent of the Latino and 64 percent of the Asian vote in 2008. Yet neither this support nor his broader popularity upon entering office, the new president believed, was sufficient to propel major policy innovation. Even in an era of partisan polarization, few issues rivaled illegal immigration for how great the divide was between the Democratic and Republican base-ideological distance replicated in Congress. ${ }^{89}$ Moreover, conflicts within each party on how to govern immigration remained profound. Obama's promise to secure sweeping immigration reform in his first year won cheers from the Democratic base on the campaign trail, but it loomed as a tall order for an untested administration.

Soon after entering office, the Obama White House announced that an immigration initiative would have to come after more looming priorities such as health care, energy, and financial regulatory reform. ${ }^{90}$ Its determination to push the issue off its action agenda was influenced by two crucial coalitional realities. First, the Obama team could not find more than one Republican senator and a handful of Republican House members willing to work across the aisle on immigration reform. Major immigration policy innovation long has hinged upon uneasy bipartisan compromises, but Republican lawmakers were in no mood to contradict hard-liners in the conservative media or to antagonize fervent anti-immigrant activists in their base. Second, the administration understood well that the issue politically exposed congressional Democrats from swing states and districts, with many publicly opposing any deal that included a "path to earned citizenship" for undocumented immigrants. These daunting impediments to building a majority coalition only compounded the bedeviling practical policy choices and broader public cynicism about comprehensive immigration reform. It is within this context that the Obama administration decided that the subject was too politically explosive to tackle at the outset. 


\section{The Congressional Dynamics of Immigration Reform}

Instead, Obama reassured restive Latino and immigrant rights groups that he was ready to lead a "difficult" fight for reform when the time was right.

However, the administration learned that it was not so easy to change the subject. Claims that undocumented immigrants would benefit from health care reform became a prominent feature of vituperative town hall meetings during the summer of 2009. They elicited a strong rebuke from Obama in his health care speech to a joint session of Congress the following fall, serving as the impetus for Representative Joe Wilson's infamous outburst, "You lie!" At the first national Tea Party Convention in Nashville, Tennessee, during the winter of 2010, immigrants and immigration reform were major topics of speeches heard by assembled delegates of the grassroots movement. In one of the most prominent keynote addresses, Tom Tancredo- the failed 2008 GOP presidential candidate and former congressman-was cheered when he fulminated that Obama was elected by naturalized immigrants and other people "who can't even spell the word "vote' or speak English." Warning rapt delegates that "our culture is at stake," he then made headlines by lamenting "we do not have a civics, literacy test before people can vote."91 The next day, Tancredo joined Roy Beck, executive director of the restrictionist Numbers USA, to argue that cracking down on illegal immigration, discouraging "chain migration" from developing countries by cutting family preferences in legal admissions, and denying birthright citizenship (jus soli) to the children of undocumented mothers were keys to solving the nation's deep social and economic woes. ${ }^{92}$ In the months that followed, the lone Republican senator who had been willing to work with Obama on immigration reform, Lindsay Graham of South Carolina, responded to pressure from his conservative base by announcing that he would seek to amend the Constitution to deny birthright citizenship to the children of undocumented immigrants. "People come here to have babies," Graham told Fox News. "They come here to drop a child. It's called, 'drop and leave.' To have a child in America, they cross the border, they go to the emergency room, have a child, and that child's automatically an American citizen. That shouldn't be the case." 93 A bipartisan congressional deal on immigration reform was impossible.

During the heat of the 2010 election, illegal immigration was again center stage. In races across the country, Republican candidates railed against "illegal aliens who take our jobs" and increase 


\section{The Congressional Dynamics of Immigration Reform}

taxes by placing strains on "health care, criminal justice, and the educational system." "94 During the hotly contested Nevada senate campaign, Republican challenger Sharron Angle ran negative ads blaming incumbent Senator Harry Reid for "millions of illegal aliens, swarming across our border, joining violent gangs, forcing families to live in fear." By contrast, Obama sought to rally Latino voter support during the waning stages of the election by renewing his pledge to secure comprehensive immigration reform. Obama reminded Univision audiences that his efforts were opposed at every turn by "anti-immigration" Republican lawmakers "who are supportive of the Arizona law, who talk only about border security ... who are out there engaging in rhetoric that is divisive and damaging." Even as Democratic control of the House slipped away, Obama said of comprehensive immigration that he was "committed to making it happen. We're going to get it done." 95

In contrast to its predecessor, the Obama administration proved unwilling to pursue comprehensive immigration reform before lining up its congressional ducks. The 2012 election returns underscored for GOP leaders and key business constituencies who employ newcomers that affixing the Republican brand to perceived anti-immigrant causes poses grave long-term electoral and economic consequences. Today a fresh strange bedfellow coalition led by bipartisan reformers in both houses of Congress has emerged to advance a grand bargain with familiar elements-legalization, a guest worker program, enhanced enforcement and border control, and employer sanctions. Significantly, the engine of comprehensive immigration reform in Congress now is not insulated client politics but the demonstrated electoral clout of new immigrants and their kindred ethnic groups. In the contemporary politics of immigration reform, lawmakers now balance the demands of well-organized lobbies and advocacy groups with grassroots constituency pressures and electoral calculations.

Today both Congress and the president have fewer degrees of freedom on immigration reform than their predecessors. "If a fight starts, watch the crowd," political scientist E.E. Schattschneider advised us nearly 50 years ago. He was reflecting on how political conflicts are profoundly shaped by their scope, and by bystanders who may enter the fray and alter the power dynamics among those politically engaged on an issue. ${ }^{96}$ The scope of conflict in American politics over illegal immigration and the future of undocumented aliens is greater now than it has 


\section{The Congressional Dynamics of Immigration Reform}

been for decades, if not ever. As we have seen, the distinctive partisan and intraparty conflicts generated by immigration policy struggles are equally important. Indeed, these unique political fissures typically mean that congressional action on immigration reform requires the formation of "strange bedfellow" alliances that are unstable and demand "grand bargains" addressing disparate goals. How Congress and Obama navigate this political minefield will have lasting social, economic, and political implications as American democracy adapts to new demography. 


\section{The Congressional Dynamics of Immigration Reform}

\section{Notes}

1. Nolan McCarty, Keith Poole, and Howard Rosenthal, Polarized America: The Dance of Ideology and Unequal Riches (Cambridge, Mass.: MIT Press, 2006); "Party Polarization in American Politics: Characteristics, Causes, and Consequences," Annual Review of Political Science Vol. 9: 83-110 (June 2006).

2. Ginger Thompson and David Herszenhorn, "Obama Set for First Step on Immigration Reform," The New York Times, June 25, 2009, accessed (date accessed), (URL); Michael Farrell, “Obama Delays Immigration Reform-At Great Risk,” Christian Science Monitor, August 11, 2009.

3. Chinese Exclusion Case, 130 U.S. 518 (1889).

4. Fong Yue Ting v. U.S. 149 U.S. 698 (1893).

5. T. H. Marshall, Citizenship and Social Class and Other Essays (Cambridge, UK: Cambridge University Press, 1950).

6. Luis Guitierrez, interview transcript in Democracy Now Radio and Television, May 2, 2006.

7. Edward Schumacher-Matos, "Immigration Reform Must Wait," North County Times, August 28, 2009.

8. Swain, Carol. Introduction to Debating Immigration, ed. Carol Swain. (New York: Cambridge University Press, 2007), 1-16.

9. Lou Dobbs, "Big Media Hide Truth about Immigration," CNN.com, April 25, 2007.

10. George W. Bush, “Address to the Nation on Immigration Reform,” May 15, 2006.

11. See Tom Tancredo, In Mortal Danger (Nashville, Tenn.: WND Books, 2006).

12. Mark Reisler, By the Sweat of Their Brow (Westport, CT: Greenwood Press, 1976), 24-32.

13. Ibid., 27.

14. Tichenor, Dividing Lines, 168-170.

15. Reisler, By the Sweat of Their Brow, 40.

16. Ibid, 175.

17. Ibid., 201. 
18. Max Kohler, Undated Notes, Max Kohler Papers, American Jewish Historical Society, Brandeis University, Waltham, MA, Box 5, Immigration Notes Folder.

19. Demarest Lloyd to Joseph Lee, May 17, 1928, Joseph Lee Papers, Massachusetts Historical Society, Boston, Massachusetts.

20. Robert Ward to Joseph Lee, May 17, 1928, Lee Papers.

21. Immigration Restriction League, Executive Committee Bulletin no. 12, June 1, 1928, Immigration Restriction League Papers, Houghton Library, Harvard University, Cambridge, Massachusetts.

22. American Federation of Labor, Proceedings of the Annual Convention, 1934 bound volume, 550, George Meany Archives, Silver Spring, Maryland.

23. U.S. Department of Labor, 26th Annual Report of the Secretary of Labor, 1938 (Washington, D.C.: Government Printing Office, 1939), 95-96.

24. Arthur Altmeyer, executive director of the War Manpower Commission, to Claude Wickard, Secretary of Agriculture, Memo on Proposed Agreement for the Importation of Mexican Workers, July 29, 1942, Box 35, Folder 26 on Mexican Labor, AFL-CIO Department of Legislation Papers, George Meany Archives.

25. Kitty Calavita, Inside the State: The Bracero Program, Immigration, and the INS (New York: Routledge, 1992), 32-35.

26. David Reimers, Still the Golden Door (New York: Columbia University Press, 1992), 54.

27. Ibid.

28. Author's interview with Rep. Henry B. Gonzalez, March, 1996; Calavita, Inside the State, 163-169.

29. Andrew Biemiller to Peter Rodino, September 8, 1972; Biemiller to Rodino, March 23, 1973; Rodino to Biemiller, May 15, 1973, Papers of the Legislation Department of the AFLCIO, Box 71, Folder \#28, George Meany Archives.

30. See, for example, The New York Times, December 31, 1974.

31. Congressional Record, September 12, 1972, 30164, 30182-83; National Council of La Raza documents made available to the author by the national office of the NCLR. 
32. White House Statement, August 4, 1977, Patricia Roberts Harris Papers.

33. "Memorandum to Interested Parties from the Mexican-American Legal Defense and Education Fund: Statement of Position Regarding the Administration's Undocumented Alien Legislation Proposal," November 11, 1977, Papers of the Leadership Conference on Civil Rights, Container \#23, “Issues: Alien Civil Rights” Folder.

34. Transcript of SCIRP meeting, May 7, 1980, 34, Record Group 240, Box 26, National Archives.

35. Lawrence Fuchs, American Kaleidoscope (Hanover, NH: University Press of New England, 1990), 252.

36. Transcript of SCIRP meeting, 34.

37. The New York Times, August 24, 1981.

38. The arduous path to the Simpson-Mazzoli legislation in 1986 is discussed in depth in Tichenor, Dividing Lines, Chapter 9.

39. E.E. Schattschneider, The Semi-Sovereign People (New York: Holt, Rinehart and Winston, 1960).

40. Author's interviews with FAIR staff, California Save our State movement leaders, and local activists.

41. Author's interview with Harold Ezell and anonymous staffer of SOS.

42. Los Angeles Times, October 29, 1994.

43. One can track the steady increase in restrictionist sentiment in Gallup Poll, Public Opinion (Wilmington, DE: Scholarly Resources, 1994), 250-51, and the American National Election Studies (Ann Arbor, MI: University of Michigan Press, 1994).

44. NBC News/Wall Street Journal poll, October 14, 1994.

45. Gallup/Chicago Council of Foreign Relations Poll, October 7, 1994, in Jack Reilly, ed., American Public Opinion and U.S. Foreign Relations, 1995 (Chicago: Chicago Council of Foreign Relations: 1995), 32.

46. Jack Citrin et al., "Public Opinion Toward Immigration Reform," Journal of Politics 59, no. 3 (1997): 858-81. 
47. Author's interviews with Republican House members; see also Dan Carney, "GOP Casts a Kinder Eye on 'Huddled Masses,"” Congressional Quarterly Weekly Reports (1999): 1127-1129.

48. Quoted in David Reimers, Unwelcome Strangers: American Identity and the Turn Against Immigration (New York: Columbia University Press, 1999), 134.

49. See the comments of Chris Smith and Mark Souter, Washington Times, March 20, 1996.

50. Wall Street Journal, June 9, 1995; and Congressional Quarterly Weekly Reports, November 25, 1995, 3600.

51. Ibid.

52. Congressional Quarterly Weekly Reports, March 23, 1996, 798.

53. Statement on Singing Executive Order on Illegal Immigration, Weekly Compilation of Presidential Documents, February 19, 1996.

54. Author's interviews with congressional members; see also 1996 Republican views of immigration as a "wedge” issue in Congressional Quarterly Weekly Reports, May 15, 1999, 1127-29.

55. Congressional Quarterly Weekly Reports, May 15, 1999, 1127.

56. William Schneider, "Immigration Issue Rewards Democrats," National Journal 28 (1996): 2622.

57. See Hispanic Magazine, January-February 2001; on earlier Republican adjustments, see Dick Kirschten, “Trying a Little Tenderness,” National Journal, (1998): 54.

58. Robert Suro, Richard Fry, and Jeffrey Passel, "Hispanics and the 2004 Election," Pew Hispanic Center Report, June 27, 2005.

59. Mike Allen, "Immigration Reform on Bush Agenda," Washington Post, 2003.

60. Immigrant Union Members Numbers and Trends Migration Policy Institute Immigration Facts, May 2004, No. 7. See also Janice Fine and Daniel Tichenor, "A Movement Wrestling: Labor's Enduring Struggle with Immigration," Studies in American Political Development, forthcoming.

61. Allen, "Immigration Reform on Bush Agenda," 1. 
62. James Lakely and Joseph Curl, "Bush will propose plan on illegals," Washington Times, 2004.

63. Wayne Washington, “Campaign 2004: Bush Upsets Part of Conservative Base,” The Boston Globe, 2004.

64. Ralph Hallow and James Lakely, “GOP slams Bush policies at retreat," Washington Times.

65. Washington, “Campaign 2004,” 1.

66. Ralph Hallow, "GOP To Finesse the Immigration Issue," Washington Times, 2004.

67. Suro et al., "Hispanics and the 2004 Election." See also "The Latino, Asian, and Immigrant Vote: 2004,” National Immigration Forum Backgrounder.

68. Bill Sammon, "Bush Revives Bid to Legalize Illegal Aliens," Washington Times 2004; and Daren Briscoe, "Immigration-A Hot Topic," Newsweek, 2004.

69. Ibid.

70. Stephen Dinan, “House Shuns Illegals Proposal,” The Washington Times, 2004.

71. Sammon, "Bush Revives Bid to Legalize Illegal Aliens."

72. Dinan, "House Shuns Illegals Proposal."

73. David Bacon

74. Jim Gilchrist and Jerome Corsi, Minutemen: The Battle To Secure America's Borders (Los Angeles: World Ahead, 2006).

75. “Immigration Issue Remains Divisive," Rasmussen Reports, March 30, 2006 (containing earlier survey results).

76. See "The 2006 Immigrant Uprising: Origins and Future," Victor Narro, Kent Wong and Janna Sahdduck-Hernandez, New Labor Forum, 16, no. 1, December (2007): 49-56; and "The Immigrant Rights Marches of 2006 and the Prospects of a New Civil Rights Movement" Bill Ong Hing and Kevin R. Johnson, Harvard Civil Rights-Civil Liberties Law Review, 42 (2007).

77. “24\% Have Favorable Opinion of Protestors,” Rasmussen Reports, May 1, 2006.

78. "Immigration Rallies Fail to Move Public Opinion," Rasmussen Reports, May 3, 2006.

79. “39\% Agree with President on Immigration,” Rasmussen Reports, May 17, 2006. 
80. “Bush OKs 700-Mile Border Fence,” CNN.com, October 26, 2006.

81. Robert Pear and Jim Rutenberg, "Senators in Bipartisan Deal on Immigration Bill," New York Times, May 18, 2007.

82. "Support for Senate Immigration Bill Falls," Rasmussen Reports, June 6, 2007; and "Why the Senate Immigration Bill Failed," Rasmussen Reports, June 8, 2007.

83. Robert Pear, "'86 Law Looms Over Immigration Fights,” New York Times, June 12, 2007; Stephen Dinan, “Grassley Admits Amnesty Mistake,” Washington Times, June 22, 2007.

84. On June 8th (34 Y:61 N) in which a majority comprised of conservative Republicans and liberal Democrats opposed the bill.

85. Carolyn Lochhead, "Democratic Poll Finds Tepid Support for Immigration Bill," San Francisco Chronicle, June 20, 2007; Angus Reid, “Americans Pick Enforcement in Immigration Debate," Global Monitor, June 11, 2007.

86. Gail Russell Chaddock, “Senate Makes a New Try for Immigration Bill,” Christian Science Monitor, June 21, 2007.

87. The actual vote was on invoking cloture, and it was $46 \mathrm{Y}: 53 \mathrm{~N}$.

88. "Latino Vote Fueling Introspection for Republicans," America's Voice, November 11, 2008.

89. Nolan McCarty, Keith Poole, and Howard Rosenthal, Polarized America: The Dance of Ideology and Unequal Riches (Cambridge, MA: MIT Press, 2006).

90. Ginger Thompson and David Herszenhorn, "Obama Set for First Step on Immigration Reform,” The New York Times, June 25, 2009; Michael Farrell, “Obama Delays Immigration Reform-At Great Risk," Christian Science Monitor, August 11, 2009.

91. Brian Kates, “Tea Party Convention’s Racial Brouhaha,” New York Daily News, February 5, 2010.

92. Ibid.

93. E.J. Dionne, "Is the GOP Shedding a Birthright?" The Washington Post, August 5, 2010.

94. See James Coburn, "Candidates Sound Off on Illegal Immigration," Edmund Sun, July 12, 2010; and Josh Kraushaar, “Tennessee Republicans Feud Over Immigration,” Politico, May 25, 2010. 
95. "Univision Transcript: Piolin Interview with President Barack Obama," October 26, 2010.

96. E.E. Schattschneider, The Semi-Sovereign People (New York: Holt, Rinehart and Winston, 1960). 